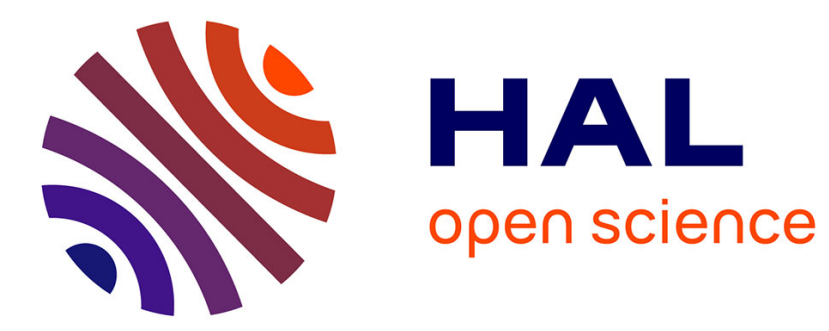

\title{
Book Review: Modern Times/Ancient Hours. Working Lives in the Twenty-first Century
}

Laura Corradi

\section{To cite this version:}

Laura Corradi. Book Review: Modern Times/Ancient Hours. Working Lives in the Twenty-first Century. Time \& Society, 2005, 14 (1), pp.155-157. 10.1177/0961463X05049951 . hal-00570988

\section{HAL Id: hal-00570988 \\ https://hal.science/hal-00570988}

Submitted on 1 Mar 2011

HAL is a multi-disciplinary open access archive for the deposit and dissemination of scientific research documents, whether they are published or not. The documents may come from teaching and research institutions in France or abroad, or from public or private research centers.
L'archive ouverte pluridisciplinaire HAL, est destinée au dépôt et à la diffusion de documents scientifiques de niveau recherche, publiés ou non, émanant des établissements d'enseignement et de recherche français ou étrangers, des laboratoires publics ou privés. 


\section{Book Reviews}

Pietro Basso, Modern Times/Ancient Hours. Working Lives in the Twenty-first Century. London: Verso, 2003. 288pp. ISBN $1859845657, £ 13.70$

This book presents a set of excellent arguments for the contemporary debate over time and work. Clear and eloquent, well supported with scientific data, the central kernel is represented by a thesis: in industrial society the average working time of wage labourers has become, in the author's words, 'increasingly burdensome and invasive - more intense, fast-paced, "flexible" and long' (p. 1).

In the last decades most attention has been spent around the perceived tyranny of time (Hochschild, 1997); fragmentation and degradation of work (Bravermann, 1974/1999), the intensification of labour in a 'flexitime' context (Odih, 2003) and the compression of time and lives (Harvey, 1990). Much has been written on time and gender and time and health (Adams, 1997), linking time contraction with stress and burn-out, in a era of precarious jobs - part-time, seasonal, contract work - and the uncertainty of future times (Leccardi, 1996). The epoch of just-in-time cities has been described, whereas synchronization becomes a must in social relations (Corradi, 1998), and survival strategies of 'time squeeze' necessary in order to realign commitments and 'free up' some time to spend with the loved ones (Southerton, 2003). All this has to do with the changing quality of our time both at work and in the sphere of so-called leisure, the latter becoming - under the hill of neoliberalism - a time of productive consumption (Corradi, 1991/2003).

Basso's work has the indubitable merit of shifting our attention from the qualitative aspect to the quantitative frame within which these phenomena take place: he is one of the few European scholars who has recognised that work is becoming more onerous, fatiguing and oppressive - by enveloping our life in a subtle yet overwhelming manner. Working hours are becoming extended at the weekly and often daily level.

In a pathbreaking analysis - grounded in Marxist theory, yet offering a wide range of references - Basso highlights the contradiction between the technological promise of more free time (let's remember Keynes's guarantee of a three-hour day) and the harsh reality of extended working hours - for a normal life of pain, so well described by Lilian Rubin (1976/1992). Basso reminds us that profit is unpaid working time - and the progressive reduction of living labour embodied in the

Time \& Society copyright (C) 2005 SAGE (London, Thousand Oaks, CA and New Delhi) VOL. 14 No. 1 (2005), pp. 155-160 0961-463X DOI: 10.1177/0961463X05049951

www.sagepublications.com 
commodity is not in contradiction with the numerical increase of industrial workers on a world scale: in the process of valorization, the reduction of the part constituted by the living labour "heightens the necessity for capital to "squeeze" the residual labour to the utmost, in intensity as well as duration' (p. 24).

The reduction of working time necessary for commodity production does not translate into a diminution of working hours: in Pietro Basso's terms, this is another 'genetic contradiction' harboured in capitalism between the social character of labour and the private character of appropriation, so that the creation of time 'free from work' takes the opposite forms of mass unemployment and the idleness of our proprietor classes.

His critique proposes a synchronical and a diachronical perspective, by reviewing both the historical and contemporary debate. Starting with those who have been forcefully opposing a reduction of the working day, from the Manchester philantropists' antagonism to the ten-hour day to Marshall's hostility to the eight-hour day, up to unmasking the exegetes of the present who maintain that working hours have been progressively shortened.

In doing so, Basso magisterially unveils the ways in which statistics are manipulated and used to lie: for example, one widely quoted study of working hours includes both children and retired people in its averages. Restating the truth becomes the path of this book, and the reader is guided through the 'horror story' that is life in modern capitalistic societies confronted by the gap between promises and reality.

In so called developing countries, where capitalist accumulation reaches its wildest acme - in the dramatic passage from domestic modes of production to salaried labour - working hours increase for everybody. The issues highlighted by Basso lead us to understand how 'Third World' conditions are a reality in our own backyards. It seems that the reality of different forms of time slavery are more difficult to cover up.

As Mike Davis pointed out introducing Basso's work, one of the merits of his urgent and authoritative investigation is that "nothing is more corrosive of social solidarity than the "American disease" of longer work hours and greater economic inequality'. Desolidarization is in the structure: unemployment is on the rise, especially among African-american males (almost twice compared to white males) while employment rates have decreased steadily since 1948 .

Basso's book, from a priviledged standpoint in the hyperproductive north-east of Italy, with an emphasis on European data, has a double merit: the first relates to the courage of swimming upstream, offering a new perspective on aspects often neglected in the context of industry-sponsored studies; the second advantage of this work has to do with the author's marble-like aptitude of unravelling the structural reasons underlying each and any process, in an exciting and polemic writing style, which does not get lost in the translation from Italian to English by Giacomo Donis. Modern Times/Ancient Hours is a milestone in the sociology of time and in the sociology of work; it is also important reading for anybody who is interested in social change, both scholarly and in the activists/unionists milieu. 


\section{References}

Adams, C. J. (1997) 'Mad Cow Disease and the Animal Industrial Complex. An Ecofeminist Analysis', Organisation \& Environment 10(1).

Bravermann, H. (1974/1999) Labor and Monopoly Capital: The Degradation of Work in the Twentieth Century. New York: Monthly Review Press.

Corradi, L. (1991/2003) Il tempo rovesciato. Milano: Angeli.

Corradi, L. (1998) 'Le città just-in-time. Per una critica del tempo neoliberale', in G. Paolucci (ed.) La città macchina del tempo. Milano: Angeli.

Harvey, D. (1990) The Condition of Postmodernity: an Enquiry Into the Origins of Cultural Change. Cambridge: Blackwell.

Hochschild, A. R. (1997) The Time Bind: When Work Becomes Home and Home Becomes Work. New York: Metropolitan Books.

Leccardi, C. (1996) Futuro breve. Torino: Rosenberg \& Sellier.

Odih, P. (2003) 'Gender, Work and Organization in the Time/Space Economy of Just in Time Labour', Time \& Society 12(2/3): 293-314.

Rubin, L. (1976/1992) Worlds of Pain. Life in the Working Class Family. New York: Basic Books.

Southerton, D. (2003) 'Squeezing Time. Allocating Practices, Coordinating Networks and Scheduling Society', Time \& Society 12(1): 5-25.

Laura Corradi, University of Calabria, Arcavacata, Italy

Henri Lefebvre, Rhythmanalysis: Space, Time and Everyday Life. London and New York: Continuum, 2004. 160 pp. ISBN 0826469930, £55 (hbk); $0826472990, £ 15.99$ (pbk).

This little book brings together Henri Lefebvre's key writings on time, in English, for the first time. Rythmanalysis contains the first full English translation of Éléments de rythmanalyse, published in 1992, shortly after Lefebvre's death, together with two earlier essays, jointly written with his last wife Catherine Régulier, 'The Rhythmanalytical Project' and 'Attempt at the Rhythmanalysis of Mediterranean Cities'. In sum, it provides the most thorough account of Lefebvre's work on time yet available to an English-speaking audience and, as such, it really demands to be read.

In an insightful introduction, Stuart Elden, Lefebvre scholar and one of the book's translators, suggests that the recent emphasis, among anglophone scholars at least, on Lefebvre's work on space has been to the detriment of his lifelong concern with time and, more especially, the conjunction of time and space in rhythm. Rhythmanalysis redresses this imbalance, making clear that Lefebvre was a theorist of time as much as of space and, above all else, insisted on the importance of thinking space and time together: spaces are timed; times are spaced. The clearest articulation of one of Lefebvre's key points is provided late in the book, in the co-authored 'Attempt at the Rhythmanalysis of Mediterranean Cities': 